\title{
Climate change litigation: A review of research on courts and litigants in climate governance
}

\author{
Joana Setzer ${ }^{1}\left([)\right.$ Lisa C. Vanhala ${ }^{2}$ (])
}

${ }^{1}$ London School of Economics and Political Science, Grantham Research Institute on Climate Change and the Environment, London, England

${ }^{2}$ Department of Political Science, University

College London, London, England

Correspondence

Lisa C. Vanhala, Department of Political Science, University College London, London, England.

Email: 1.vanhala@ucl.ac.uk

Funding information

British Academy; Economic and Social Research Council, Grant/Award Number: ES/K008153/1;

H2020 European Research Council

Edited by Mike Hulme, Editor-in-Chief
Studies of climate change litigation have proliferated over the past two decades, as lawsuits across the world increasingly bring policy debates about climate change mitigation and adaptation, as well as climate change-related loss and damage to the attention of courts. We systematically identify 130 articles on climate change litigation published in English in the law and social sciences between 2000 and 2018 to identify research trajectories. In addition to a budding interdisciplinarity in scholarly interest in climate change litigation we also document a growing understanding of the full spectrum of actors involved and implicated in climate lawsuits and the range of motivations and/or strategic imperatives underpinning their engagement with the law. Situating this within the broader academic literature on the topic we then highlight a number of cutting edge trends and opportunities for future research. Four emerging themes are explored in detail: the relationship between litigation and governance; how time and scale feature in climate litigation; the role of science; and what has been coined the "human rights turn" in climate change litigation. We highlight the limits of existing work and the need for future research-not limited to legal scholarship - to evaluate the impact of both regulatory and antiregulatory climate-related lawsuits, and to explore a wider set of jurisdictions, actors and themes. Addressing these issues and questions will help to develop a deeper understanding of the conditions under which litigation will strengthen or undermine climate governance.

This article is categorized under:

Policy and Governance > Multilevel and Transnational Climate Change Governance

\section{KEYWORDS}

climate change litigation, climate governance, climate lawsuits, regulation

\section{1 | INTRODUCTION}

Courts are playing an increasingly visible role in policy debates about climate change mitigation and adaptation, as well as climate change-related loss and damage. ${ }^{1}$ Lawsuits addressing the causes and consequences of climate change- - such as the expansion of airports, the reliance on coal-powered energy and the climate-related erosion of the habitats of endangered species-are increasingly apparent in national courts, and scholars even see a potential role for international tribunals to address climate harms (e.g., Bodansky, 2017; Sands, 2016). This article is, to our knowledge, the first to systematically review key literature on climate change litigation over the last 20 years. We build on this to identify new horizons for a forward- 
looking research agenda. We highlight key research trajectories and identify opportunities for interdisciplinary engagement in developing theory, in expanding our empirical knowledge of the phenomenon and in promoting the application of a range of methodological approaches that will build on existing knowledge.

Our review is based on a two-step process. First, we draw on a systematic review of 130 academic articles on climate change litigation published in English in the law and social sciences between 2000 and the end of September 2018. Second, we situate this within the broader academic literature on the topic and draw on our knowledge of research in related fields. The review shows that it is possible to observe different trajectories that the climate litigation literature has been following: from a dominance by legal scholars to a growing interdisciplinarity; from a focus on certain types of cases and key playersnamely plaintiffs resorting to the courts to press for concrete action in order to tackle climate changerange of actors studied and greater attention being paid to the full range of motivations and/or strategic imperatives behind their legal challenges. While early work paid close attention to the causes of action, arguments about standing, and the difficulty with establishing causality in climate change lawsuits (Averill, 2008; Burns \& Osofsky, 2009; Faure \& Nollkaemper, 2007; Harrington, 2007; Lin, 2012; Millner \& Ruddock, 2011; Osofsky, 2005a, 2005b, 2010; Preston, 2009; Schatz, 2009), more recent research has engaged with a broader set of questions about the relationship between legislation, regulation and litigation domestically (see e.g., Peel \& Osofsky, 2015; Preston, 2016a; Setzer \& Nachmany, 2018; Vanhala, 2013), and the potential for climate litigation to contribute to effective enforcement of international climate law (Butterfield, 2018; Carnwath, 2016).

This review highlights a number of gaps in existing research and suggests that building bridges between disciplinary approaches is a fruitful way forward. For example, the bodies of literature on the "climate change regime complex," "polycentric governance of climate change," and "climate justice" (Abbott, 2014; Keohane \& Victor, 2011) have largely ignored the governance and normative roles that can be played by judiciaries and the litigants that prompt them to action (but see Bodansky, 2017; Osofsky \& Peel, 2013; Sands, 2016). Yet we know from other areas of research, such as in the field of human rights, that domestic and international courts and those who appear before them matter. The socio-legal literature shifts focus onto the agents that mobilize the law, which helps us better understand why some issues are brought before the courts while others are not. But socio-legal scholars have only relatively recently begun to explore the field of climate policy. Emerging research suggests important interdisciplinary potential in terms of the types of questions being asked and the variety of actors receiving analytical attention (Fisher, 2013; Osofsky, 2007a, 2007b; Vanhala \& Hilson, 2013). Finally, methodological questions about how to define and measure the "impact" of climate change litigation are starting to be debated both within and across disciplines (Keele, 2018).

The article is structured as follows. We begin by providing an overview of the literature on climate litigation based on a systematic search of journal articles on climate litigation. We highlight some general trajectories of research on climate litigation-from dominance by lawyers to interest among social scientists, and from a focus on certain actors (e.g., NGOs and oil producers) to a broadening of the types of litigants and actors that are involved in climate change litigation. We then explore four key and emerging themes in the interdisciplinary literature on climate change litigation: the relationship between litigation and governance; how time and scale feature in climate litigation; the role of science in climate change litigation; and what has been coined the "human rights turn" in climate litigation (Peel \& Osofsky, 2018). For each of these we highlight emerging findings, key gaps in understanding and future avenues for research. Finally, we turn to a discussion of some of the challenges of research on climate change litigation including issues of measurement and selection bias in case selection and the pressing need for research examining the outcomes and impact of climate change litigation.

\section{I OVERVIEW OF THE LITERATURE ON CLIMATE CHANGE LITIGATION}

We reviewed 130 academic publications on climate change litigation that were identified through a systematic search of the Scopus and Web of Science databases, HeinOnline and Google Scholar. In our dataset we included English-language publications in academic journals published between 2000 and the end of September 2018 that contained the search terms "climate" and "litigation" in the title and/or abstract. In the systematic analysis, we do not include books or book chapters. However, in the discussion below we reference a broader set of literature, including books, chapters and articles that do not meet the above criteria in order to draw out key lessons and linkages. As such, this review draws on the systematic survey of the literature as a starting point and does not claim to be a fully complete assessment of all publications on climate litigation. ${ }^{2}$

\section{1 | Increased interest and its pattern}

While a few articles on the topic were published in the early 2000s (e.g., Hodas, 2000; Grossman, 2003), over the last 15 years there has been a marked increase in scholarly interest in climate change litigation (Figure 1). 


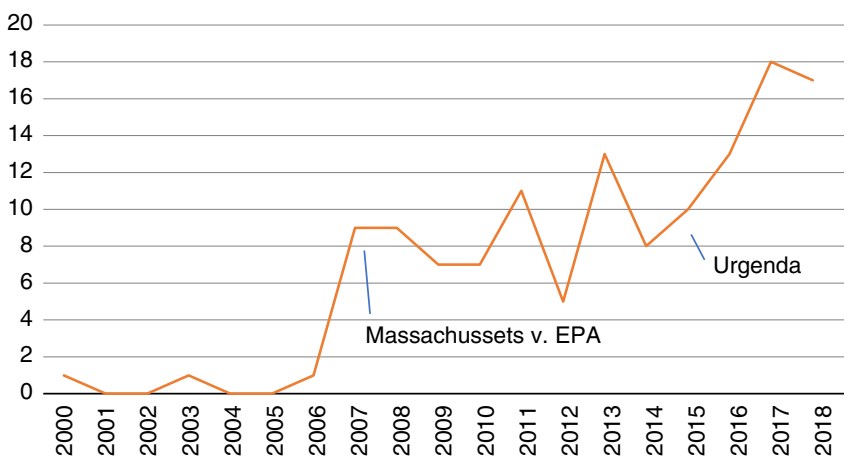

FIGURE 1 Timeline of the number of journal publications per year that contained the search terms "climate" and "litigation" in the title and/or abstract, up until September 2018, with high-profile lawsuits annotated. Note that in the case of Massachusetts v. EPA, the petition was filed in 1999, and 2007 is the year in which the Supreme Court issued its ruling, siding with the petitioners. In the case of Urgenda v. Kingdom of the Netherlands, the summons was filed in 2013, and 2015 is when the District Court of The Hague issued its ruling, siding with the petitioners (which in October 2018 was upheld by the Hague Court of Appeal)

The pattern over time suggests that there may be several drivers for the growth in scholarly attention to this topic. One driver may be high-profile judgments such as the 2007 Supreme Court decision in Massachusetts v. EPA (see Fisher, 2013; Osofsky, 2010; Watts \& Wildermuth, 2008). Similarly, we see what we call the "Urgenda effect" on climate litigation research following the original 2015 Urgenda decision in the Netherlands. Since this high-profile case, where the Urgenda Foundation won a legal case to compel the state to take more effective action to address climate change, there has been a sustained spike in publications on climate litigation including more than a dozen analyzing the Urgenda case in an in-depth or comparative manner (Bergkamp, 2015; Bergkamp \& Hanekamp, 2015; Butterfield, 2018; Cox, 2016; de Graaf \& Jans, 2015; Ferreira, 2016; Peel \& Osofsky, 2018; Peeters, 2016; Roy \& Woerdman, 2016; Schiermeier, 2015; Ugochukwu, 2018; Van Zeben, 2015). The 2018 decision of the Hague Court of Appeals to uphold the lower court ruling is likely to maintain or spur future scholarship.

Relatively few studies have looked into what constitutes the lion's share of climate litigation activity-hundreds of routine or "everyday" cases dealing with, for example, planning applications or allocation of emissions allowances under the EU Emissions Trading System. Such cases might also have some impact on the behavior and decisions of governments or private parties (but see Bogojević, 2013; Keele, 2018; Markell \& Ruhl, 2012; Osofsky \& Peel, 2013; Peel \& Osofsky, 2015; Vanhala, 2013). As Bouwer (2018, p. 9) argues, "preoccupation with 'holy grail' cases can obscure both the instrumental potential, and possible implications, of much less visible forms of litigation about climate change."

Another driver has been a series of key books and special issues in different journals that have raised scholarly awareness of the phenomenon across disciplines and sparked further publications. These have included an edited volume on climate change adjudication (Burns \& Osofsky, 2009); a 2013 interdisciplinary symposium on climate change litigation in Law \& Policy; Peel and Osofsky's (2015) monograph Climate Change Litigation: Regulatory Pathways to Cleaner Energy; and a special issue in 2016 of the Journal of Environmental Law.

A first examination of this body of literature points to the variety of different ways in which scholars are defining the term "climate change litigation" and measuring it. There are as many understandings of what counts as "climate change litigation" as there are authors writing about the phenomenon (see for example, Bouwer, 2015; Burns \& Osofsky, 2009; Ghaleigh, 2010; Hilson, 2010, 2012; Markell \& Ruhl, 2010; Peel \& Osofsky, 2015; Preston, 2011a; Preston, 2011b; Schatz, 2009; Setzer \& Bangalore, 2017; Vanhala \& Hilson, 2013). For instance, cases dealing with the causes of climate change (e.g., coal plants) that do not explicitly mention climate change are not included in existing datasets, yet they might play a profound role in shaping a country's energy policy and greenhouse gas (GHG) emissions (Bouwer, 2018). Some scholars include cases both supporting and opposing regulation of GHG emissions as climate change litigation whereas others include only the supportive cases.

Similarly, while the frame of climate change-related loss and damage has been only relatively recently institutionalized in the UN regime, there is evidence that the number of "adaptation" and "loss and damage" cases is growing. Yet how is one to assess whether cases dealing with the consequences of more frequent and extreme weather events (that do not happen to have the words "climate change" in the legal arguments or law reports or in the media narrative about the case) should count as a "loss and damage" case? In some ways, this will depend on the research question being posed. We do not see the need for an overarching definition but rather urge scholars to be clear about how they are conceptualizing and operationalizing their ideas about what climate litigation is and is not. It is also important to think about what is "comparable" in cross-jurisdiction or 
cross-cultural research. Having clarity of such caveats will facilitate interdisciplinary dialogue and enhance the potential for future meta-analyses that are able to draw on numerous studies to identify trends over time and across jurisdictions.

Mindful of such considerations, we sought to categorize the papers according to the type of different policy responses involved in the litigation to address climate change. We found that most papers were concerned with litigation to address mitigation (113 papers referred to mitigation-relevant litigation), 50 referred to adaptation-relevant litigation (e.g., He, 2018; Markell \& Ruhl, 2010; O'Donnell, 2016; Peel, Godden, \& Keenan, 2012; Preston, 2016b; Wilensky, 2015), and 20 papers referred to litigation concerned with addressing climate-related loss and damage (e.g., Hinteregger, 2017; Marjanac \& Patton, 2018; Mayer 2014; Preston, 2016b; Spitzer \& Burtscher, 2017). The 49 papers addressed both mitigation, adaptation and/or loss and damage (Figure 2).

Of the 130 articles identified systematically, 99 (76\% of the total dataset) focus on Global North jurisdictions (either in an in-depth analysis or as part of a comparative project), 26 (20\% of the total dataset) have an international focus or cover jurisdictions in both North and South. Only five of the identified journal articles have a clear focus on litigation or litigation-related issues in the Global South (He, 2018; Humby, 2018; Nyinevi, 2015; Ugochukwu, 2018; Williams, 2012) (Figure 3). Other contributions to the literature on climate litigation in Global South countries can be found in edited books (Lord, Goldberg, Rajamani, \& Brunnée, 2011) and as book chapters (Lin, 2015), but a first comprehensive study focused on Global South climate litigation is yet to be published.

In a working paper, Peel and Lin (2018) identify a number of key characteristics of climate cases in the Global South. Some are similar to those observed in the Global North, for instance, the reliance on constitutional rights or human rights claims, and the use of litigation to compel governments to implement and enforce existing policies for mitigation and adaptation. But Peel and Lin observe characteristics that are unique to Global South climate litigation. For example, that litigants connect the "peripheral" nature of climate issues to a need to embed concerns about climate change in wider disputes over constitutional rights, environmental protection, land-use, disaster management and natural resource conservation. They also observe that cases in the Global South are being brought in partnership with advocates from the Global North, resulting in benefits for both sides (Global South advocates gain knowledge and financial resources, while Global North organizations gain moral legitimacy and positive exposure via media and public awareness-raising campaigns). In another working paper, Setzer and Benjamin (2019) suggest that strategic climate litigation in the Global South is further impacted by regulatory advantages in certain jurisdictions, the boldness of activist judges, and a higher concern about the impacts of climate change and the vulnerability of their populations.

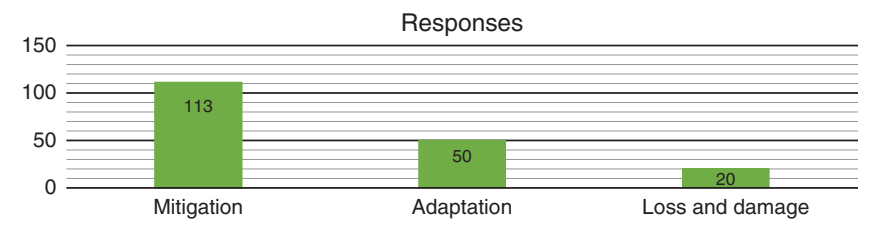

FIGURE 2 Climate litigation papers with regard to broad recurring themes (mitigation, adaptation, loss and damage) that they engage with

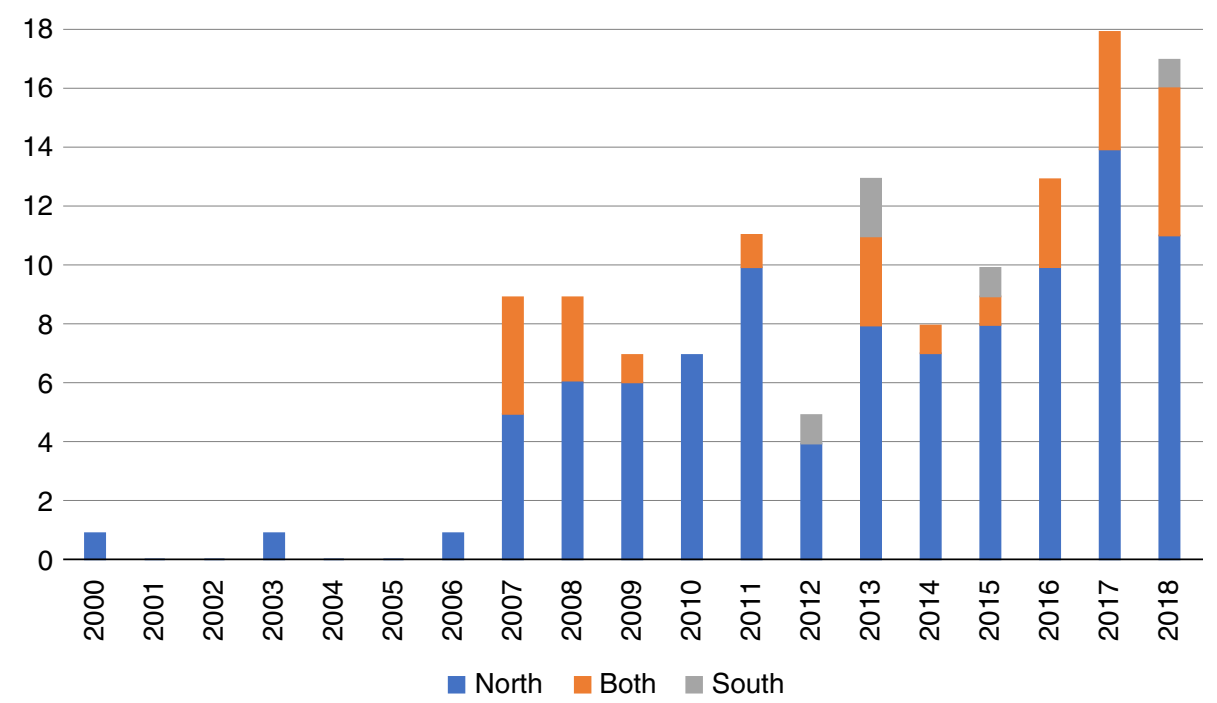

FIGURE 3 Distribution of articles examining climate litigation in the Global North ("North"), articles that have a clear focus on litigation or litigationrelated issues in the Global South ("South"), and articles that have an international focus or cover jurisdictions in both North and South ("Both") 
To a large extent, the literature reflects the concentration of lawsuits in relatively small number jurisdictions. The existing datasets for climate litigation cases identify over 920 entries $^{3}$ in the United States, and only around 270 cases in the other 28 jurisdictions, most of these in Australia (97), the United Kingdom (46), followed by New Zealand (16), Canada (14), and Spain (13). ${ }^{4}$ These jurisdictions are broadly covered by the scholarship: the United States (Colares \& Ristovski, 2014; Markell \& Ruhl, 2012), the United Kingdom (Hilson, 2010), Australia (Bartel, McFarland, \& Hearfield, 2014; Peel, 2007; Preston, 2011a). A smaller number of scholars have engaged in doing comparative studies between these jurisdictions (Okonkwo, 2017; Peel et al., 2012; Peel \& Osofsky, 2015; Schatz, 2009; Vanhala, 2013). But, once again, while the number of legal cases in the Global South has been growing in quantity and importance (e.g., Pakistan, India, the Philippines, South Africa, Colombia, and Brazil), these are yet to receive much scholarly attention (but see Peel \& Osofsky, 2018; Peel \& Lin, 2018). Some scholars have explicitly called for increased attention to trends outside of the U.S. context (Lin, 2012; Setzer \& Bangalore, 2017; Vanhala, 2013; Wilensky, 2015) and there is also a need for more scholarship on litigation (or lack thereof) in civil law jurisdictions outside of Europe and in authoritarian regimes.

\section{2 | Trajectories}

In addition to the growth in the volume of research on climate change litigation, it is possible to observe two main trajectories that the climate litigation literature has been following: one which focuses on the growing diversity in disciplinary and interdisciplinary perspectives on the topic; and one concerned with the expanding range of actors involved in the lawsuits. A summary of the different disciplines, which in turn give disparate levels of analytical attention to the range of actors and to the various stages of the litigation process, is presented in Figure 4.

\subsection{1 | Disciplinary approaches}

The first decade of research on climate change litigation was dominated by legal scholars (Burns \& Osofsky, 2009; Carlarne, 2010; Gerrard \& Freeman, 2007; Humphreys, 2009; Lord et al., 2011; Markell \& Ruhl, 2012). Peel and Osofsky (2013) identify a "first wave" of research on climate litigation as typically consisting of the development of legal arguments that could be used in climate change cases, descriptive single jurisdiction studies or chronicles of specific legal cases. Research on the possibilities and impact of U.S. tort litigation to address climate change is illustrative of this type of research (see e.g., Divisek, 2011; Eisenstat, 2011; Flynn, 2012; Kysar, 2011; Manus, 2014; Sorenson, 2012). Peel and Osofsky describe a "second wave" of research as being more analytical and systematic in the development of typologies based on the type of litigant, the legislative basis, the type of court, and so forth. Different reports and policy documents have since contributed to this type of analysis, surveying global climate change litigation, its trends and key issues that courts must resolve in the course of climate change cases (see Burger et al., 2017; Nachmany \& Setzer, 2018; Setzer \& Bangalore, 2017). Building on the insights of "second wave" research, Peel and Osofsky (2015) were part of a group of scholars that began to explore the regulatory impact of legal cases. What they describe as a "third wave" of research is concerned with examining the outcomes of climate change litigation, including how it has both influenced climate regulation and acted as such regulation (Keele, 2018; Peel \& Osofsky,

Disciplinary differences in focus of attention on various stages and different actors in this process
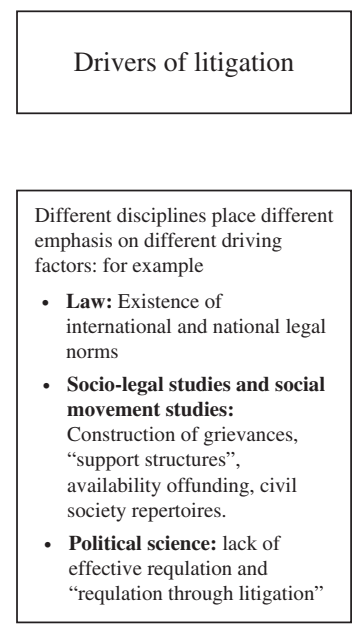

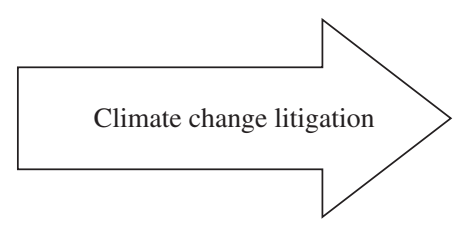

Analytical focus tends to vary by discipline:

- Law: Analysis of innovative legal arguments and development of climate change jurisprudence

- Socio-legal studies:

Framing of specific

concepts in litigants claims and in emerging jurisprudence
Impact of litigation

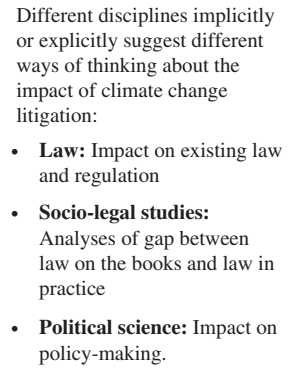

Different disciplines implicitly or explicitly suggest different ways of thinking about the impact of climate change litigation:

- Law: Impact on existing law and regulation

- Socio-legal studies: Analyses of gap between law on the books and law in practice

- Political science: Impact on policy-making. 
2013, 2015). In some senses, these waves are not sequential: there is still much research (and need for such research) published in legal journals that falls into what has been described as the "first wave" (see e.g., Blumm \& Wood, 2015; Kysar, 2018; Peel \& Osofsky, 2018; Spitzer \& Burtscher, 2017; Vollmer, 2018).

While legal scholars naturally put law and the judgments of courts at the center of their analyses, sociolegal scholars have long pointed out that there is much to be learned from de-centering the analysis of law (Haines \& Reichman, 2008). Yet climate change litigation has, until relatively recently, been largely overlooked by socio-legal scholars and by law and courts researchers in political science, sociology, and anthropology (for important exceptions see work that takes a socio-legal approach by legal scholars such as, Duyck, Jodoin, \& Johl, 2018; Fisher, 2013; Fisher, Scotford, \& Barritt, 2017; Hilson, 2010, 2012; Peel \& Osofsky, 2015 and research by social scientists, e.g., Haines \& Reichman, 2008; Hayes, 2013; Ley, 2018; Vanhala, 2013). These approaches have a great deal to bring to research on climate change litigation. For example, work on legal mobilization to address climate change could address some of the important unasked questions in existing legal scholarship. It could explore the sources of climate change cases or the "support structure" for litigation-that is, the community of willing and able litigants (particularly collective actors) (Epp, 1998). Furthermore different variables-including variation in the construction of grievances (Hilson, 2010); differing levels of resources (Galanter, 1974); the impact on litigation of different levels of access to justice or types of "legal opportunity structures" (Andersen, 2005; Doherty \& Hayes, 2011; Hilson, 2002; Vanhala, 2013, 2016, 2018) and the types of values and ideas an organization holds (Hilson, 2002; Vanhala, 2018)have all been shown to have an impact on the willingness and ability of activists, NGOs, and corporate actors to turn to the courts. Many of these issues are only just beginning to be explored in the context of climate litigation, yet they profoundly shape the landscape of legal cases.

Political scientists and political sociologists studying judicialization are sensitive to the political role courts can play and their inherent limitations as drivers of social change, but they have not yet explored climate change policy (for exceptions, see, e.g., Hayes, 2013; Vanhala, 2013). By contrast, comparative political scientists and sociologists have studied the domestic politics of climate change governance (see e.g., Giddens, 2009; Harrison \& Sundstrom, 2010) but have completely excluded the role of the courts and litigants in their analyses. Research on transnational climate governance reveals the role of a number of non-state actors and institutions in driving climate ambition (Andonova, Betsill, \& Bulkeley, 2009; Bulkeley et al., 2014), but has overlooked the role that courts play in enforcing, interpreting, or developing the law (Setzer \& Nachmany, 2018). Similarly, international relations scholars interested in the climate change regime complex look at a plethora of regulatory and governance institutions involved with the management of climate change (Abbott, 2014; Keohane \& Victor, 2011), yet fail to consider the role of international courts and tribunals in their analyses. International legal scholars (see e.g., Bodansky, 2017; Sands, 2016) and political theorists (e.g., Caney, 2005) are stepping into this gap.

Sociology and anthropology offer potentially fruitful new directions in understanding the societal relevance of climate change litigation. The literature on social movements has influenced research on strategic framing within climate change cases (Franta, 2017; Hayes, 2013; Hilson, 2012, 2018). Research in psychology on the cognitive hurdles to understanding climate risks has also been drawn on to explore effective narrative strategies in climate change litigation (Hilson, 2019; Nosek, 2018). This shows a growing diversification of ways of analytically engaging with the topic of climate change litigation.

\subsection{2 | Key players in climate change litigation}

As research on climate change litigation has become more interdisciplinary, the range of actors receiving analytical attention has also evolved. Early research focused on individual and NGO litigants taking cases against government and corporations as a way to take action to address GHG emissions. Scholars later began to pay attention to how industry actors and government officials have also used litigation to fight tighter regulatory controls (Hilson, 2010; Markell \& Ruhl, 2012; Setzer \& Bangalore, 2017). Socio-legal scholarship and social movement research has contributed to a growing awareness of the range of litigants and other actors associated with climate change litigation: from climate activists in criminal trials (Hayes, 2013), to the fossil fuel divestment movement (Franta, 2017), subnational governments (Osofsky, 2005a, 2005b, 2007a, 2007b), climate change denial groups (Ley, 2018), judges (Carnwath, 2016; Preston, 2016a; Weaver \& Kysar, 2017), and legal scholars (Fisher, 2013).

Not surprisingly, major carbon and oil producers are responding as plaintiffs in private climate change-related lawsuits. Scholars identify the potential effectiveness of targeting a relatively small group of corporations who are responsible for a large percentage of emissions (Ganguly, Setzer, \& Heyvaert, 2018; Hsu, 2008). This trend was supported by Richard Heede's (2014) work, which was the first to map and quantify the cumulative emissions of the 90 largest carbon producers (the "Carbon Majors") from 1854 to 2010 (see also Frumhoff, Heede, \& Oreskes, 2015). Surprisingly absent from courts in climaterelated cases and from the scholarship is the transport sector (e.g., aviation), international shipping, car manufacturers) and the meat industry (but see Hilson, 2010; Fisher, Scotford, \& Barrit, 2017). The special report by the UN's Intergovernmental Panel on Climate Change stresses the urgency of strong action across all transport modes (IPCC, 2018). Recent studies also suggest 
that a small number of "Meat Majors" are responsible for more annual GHG emissions than Exxon, Shell, or BP (Grain, 2018; Ritchie, Reay, \& Higgins, 2018). Other players that have received less explicit scholarly attention include scientists involved in climate litigation (but see Ley, 2018 and the discussion below) and the funders of climate change litigation.

Also surprising is how little attention has been given by the academic literature to actors from the financial sector, such as banks, institutional investors, insurance companies, corporate borrowers, and financial supervisory authorities and regulators in climate litigation (but see Franta, 2017). Finance plays a central role in climate change. Banks and investors can finance the projects that aim to support communities in their adaptation to, or mitigation of, climate change, but they also finance the projects that aggravate climate change. This latter fact is being recognized in recent climate justice litigation in which financial services providers have been sued (e.g., Abrahams v. Commonwealth Bank of Australia, 2017). Similarly, central banks in the Eurosystem risk legal challenges against them for failing to take into account environmental protection when designing and implementing monetary policy in the Eurozone (Solana, 2018). In addition, banks and pension fund schemes are under growing pressure to develop their approach to climate risk in line with improving data and market practices at the risk of facing litigation (Benjamin, 2017, 2019; Carney, 2018; ClientEarth, 2018).

\section{I KEY THEMES AND EMERGING ISSUES}

The argument that climate governance cannot be fully accomplished via the intergovernmental regime is, of course, not novel (Rayner, 2010). Many ideas for reform have been floated, and a large number of those have focused on how governance can be made more diverse, just and multi-leveled. What is still missing from both the climate governance and the climate litigation perspectives is a deeper understanding of the extent to which litigation is an effective tool to strengthen climate governance. We begin to approach this question by looking at how climate litigation relates to four key themes: legislation, scales and time, science, and human rights. For each one of these we highlight emerging issues and future avenues for research.

\section{1 | The relationship between climate litigation and legislation}

Some early research on climate change litigation tended to suggest (implicitly or explicitly) that climate litigation activity is related in some way to (at least) one of three possible governance phenomena. First, the failure to reach agreement on a comprehensive, binding international treaty to limit GHG emissions at the UNFCCC Conference of the Parties in Copenhagen in 2009 was seen as a major driver of climate change litigation (Gupta, 2007; Peel \& Osofsky, 2015; Preston, 2011a; Vanhala, 2013). Second, litigation activity was understood to be a response to the existence as well as the dearth of climate change regulation at the national level; key cases in Canada and the United States in the early 2000s are emblematic (Michaelowa, 2007; Okonkwo, 2017; Vanhala, 2013). Third, scholars noted that in some cases courts were understood as venues in which to support, contest or augment the implementation and enforcement of climate legislation (Peel, 2011; Preston, 2011a). According to this work, climate litigation emerged as a response to institutional failures at both the international and national level and as an instrument to debate, enforce, augment, or challenge climate legislation (Hilson, 2010; Peel, 2011; Preston, 2011a; Vanhala, 2013). However, today's context is considerably different, and this evolution has affected the three governance phenomena that may have been initially driving climate litigation.

The first argument - that climate litigation emerged as a response to the failure of the international community to reach an agreement - has in many ways been complicated by the adoption of the Paris Agreement. The Agreement ${ }^{5}$ broke new ground in international climate policy, acknowledging the primacy of domestic politics in climate change policy-making and allowing countries to set their own level of ambition for climate change mitigation (Falkner, 2016). The proximity of the new international climate regime to national politics now motivate scholars and potential litigators to ask if litigation can be deployed to support the implementation of the Paris Agreement and/or of the nationally determined contributions (NDCs) submitted by each Party (Butterfield, 2018). ${ }^{6}$ Some argue that, a priori, the influence of the judiciary in the climate change debate is inconsistent with the doctrine of separation of powers and with the notion of representative democracy (Bergkamp \& Stone, 2015). Others suggest that, while the Paris Agreement does not provide litigants with a cause of action or impose enforceable limits on member countries' national emissions, litigation has a "supporting goal" in the implementation of the Agreement (Burger et al., 2017), providing a landmark against which litigants can measure the actions of their governments or private entities (Carnwath, 2016).

The second argument, that litigation responded to the existence or absence of legislation, also calls for a re-evaluation. Today there are more than 1,500 climate laws and policies worldwide (Nachmany \& Setzer, 2018). All Paris Agreement signatories have at least one law addressing climate change or the transition to a low-carbon economy and 139 states have framework laws that address climate mitigation and/or adaptation holistically. National legislation regulating emissions or promoting adaptation forms a substantial legal basis on which further action-including litigation—builds (Setzer \& 
Nachmany, 2018). However, in some contexts litigation will be aimed at deregulating, undermining climate change protections or targeting climate protection supporters (Adler, 2018). What is needed now is a better understanding of whether litigation in such a "legislation-rich environment" is strengthening or weakening climate governance. Relatedly, there are also debates about the extent to which litigation can act as a complement or a substitute for legislation (Colares \& Ristovski, 2014; Dumas, 2017; Osofsky, 2010). Similarly, the growing number of climate legal cases globally can help us to explore whether litigation is playing an increasingly important and/or complementary role in the enforcement of legislation and implementation of countries' international emission reduction commitments.

The argument that litigation was needed to support, contest or augment the implementation and enforcement of climate legislation also needs further exploration. An avenue for exploring how climate litigation interacts, influences and is shaped by the policy process might be provided by the larger literature on law and politics and socio-legal studies. For instance, literature on the political economy of procedural rights spells out how and when litigation can be used as an enforcement mechanism for the regulation of diffuse environmental public goods (Coglianese, 1996). Dumas (2017) finds that citizen suits (public law litigation) affect the power balance that underpins the legislative process itself; for instance, because legislators and their constituencies are aware that litigation will transform the bills they draft. Similarly, the literature shows that the mobilization of law by a broad base of citizens or dedicated civil society actors can serve as a third-party enforcement mechanism (Melnick, 1983; Rajamani, 2007; Zemans, 1983). Another avenue for further research is to explore the ways in which the legal opportunity structures-or the rules of the game for climate litigation in different jurisdictions—are shaped by key actors, such as governments, NGOs, and corporations in ways that might influence future success or failure in litigation efforts (Vanhala, 2013, 2018). Ultimately, climate change litigation will be ineffective as a mechanism for advancing mitigation and adaptation goals if overruled by technical legal hurdles around standing, costs, definitions of what a "political question" is, and separation-of-powers issues (Peel \& Osofsky, 2015).

Finally, it is also important to bear in mind that the phenomenon of "regulation through litigation" faces a number of critiques. Some are ideological or normative-for example, those which accuse judges of being "activist" when they weigh in on debates about climate change policy, or those which argue more broadly that the judiciary weighing in on policy questions is inconsistent with the notion of representative democracy and interferes with the idea of separation of powers (Bergkamp \& Stone, 2015). Others argue, as we discuss further below, that courts lack the necessary scientific expertise to address questions related to climate change (see Jasanoff, 1995).

\section{2 | The relationship between litigation, scales, and time}

A second emerging theme involves exploring the scales and framing of time involved in climate lawsuits. Scholars have observed how addressing climate change requires the involvement of multiple-scales of governance, with a shift from the international and national to local levels, and with more functions of the national state performed by subnational and local governments (Bulkeley \& Betsill, 2005). Initially this shift involved subnational governments compensating for insufficient regulation at the national and international levels (Michaelowa \& Michaelowa, 2017). In the post-Paris period, there are a growing number of examples of subnational governments establishing their own climate-related commitments (Biniaz, 2017; Setzer, 2017). Such localization of climate governance is cited as a positive feature of a polycentric governance approach (Jordan, Huitema, Van Asselt, \& Forster, 2018; McGinnis, 2015; Ostrom, 2009).

Research in the field of law and geography has shown that processes of rescaling are also observed in climate litigation. Claims against government entities to shape regulatory behavior and legal cases against corporate emitters to limit emissions all bring a global problem to subnational, national, and regional courts (Osofsky, 2005a, 2005b). This research has highlighted the challenges of the multi-scalar terrain in which climate litigation develops. A scalar analysis of climate litigation, such as that applied by Osofsky (2007a, 2007b) to the Massachusetts v. EPA (2007) case, involves an examination of the differing scales represented by the petitioners and respondents, the use of science and scale in causal claims made by petitioners and respondents, and the implications of these approaches for efforts to use science as a tool for and against regulation.

Adding the perspective of time into this discussion, Hilson (2018) explores how time features as a frame in legal mobilization against climate change. Through an analysis of temporal framing in a number of high-profile climate litigation cases, he argues that there is a tension between a future-looking scientific time frame on the one hand, and on the other hand an environmental policy-based framing of time that is present-focused. Under future-looking scientific framing, the effects of dangerous climate change have not yet occurred and remain some way off in the "modeled" future. Under an environmentalist policy time frame and a present scientific time frame, action is needed immediately and climate harm is already happening or is imminent.

Contemporary legal cases reinforce the view that climate litigation involves many scales and time frames. The case of Lyuia v RWE AG (2017), for example, links the global phenomenon of climate change to a localized claim about individual lives, livelihoods, and traditional cultural practices. In this case, a Peruvian farmer is supported by Germanwatch, an NGO 
based in Germany but with a transnational scope; the respondent is RWE, Germany's largest energy company, but its GHG emissions and their impacts are experienced worldwide, including in the Peruvian Andes. The plaintiff comes from one of many local communities experiencing the effects of global climate change. The case also brings together many time frames. It is based on historical data of RWE's emissions (past), meteorological data (present), and models and predictions of how the village of Huaraz will be affected by increasing temperatures (future). It uses the backward-looking concept of liability to make current actors liable for their past behaviors, and tries to avoid in the present the consequences of events that might happen in the future (Hilson, 2018).

Multiple time and space frames can also be observed in the lawsuits brought by U.S. states and cities against fossil fuel companies. State of Rhode Island v. Chevron (2018), and a number of legal challenges brought by cities and counties (including Santa Cruz v. Chevron Corp. (2017); City of Oakland v. BP p.l.c. (2017); City of New York v. BP p.l.c. (2018); Board of County Commissioners of Boulder County v. Suncor Energy (U.S.A.), Inc. (2018); and King County v. BP p.l.c. (2018)) seek to secure compensation for ongoing damages and help to finance adaptation measures. Similar to the Lyuia case, the framing processes in these lawsuits localize the global effects of climate change to specific communities; at the same time, they put responsibility on to global corporations who produced oil and gas in the first place.

Researchers are yet to explore to what extent the multiple scales represented by the actors, jurisdictions, and legislation involved in these cases constitute a form of polycentric governance (Ostrom, 2009)—which, in turn, can produce the necessary pattern of governing needed to address climate change (Ostrom, 2010). Moreover, while high profile cases have been trying to localize the global challenge of climate change, some scholars argue for the importance of using local and first instance courts more effectively rather than just focusing on high-profile cases. Arguably, "small and mundane domestic and local disputes" could also make a contribution to coherent national climate policy (Bouwer, 2018, p. 11). Finally, the socio-legal literature on climate change can further explore time as an element intrinsic to, but also separate from, scale and place.

\section{3 | The relationship between climate litigation and science}

A third emerging theme in climate litigation has been the role of science and expertise in climate change litigation. Science plays a central role in climate change cases. Climate science, for example, can be critical to determining whether litigants have standing to sue. In Massachusetts v. EPA, the US Supreme Court ruled that the state of Massachusetts (and other plaintiffs including a number of states and cities) had standing because scientific research supported the link between climate change and the inundation of state-owned and managed coastal land for which the state has a public trust responsibility. Scientific research is also critical to substantiating claims that defendants' actions have caused the plaintiffs' alleged harm (McCormick et al., 2018a). In Urgenda v. Kingdom of the Netherlands, the court relied heavily on the IPCC reports to define the percentage reduction in GHG emissions the government would need to achieve to avert imminent dangers linked to climate change.

A larger challenge has been for scientists and lawyers to establish a causal link between a particular source or group of sources of GHG emissions and specific climate-related harms. In legal terms, this means establishing the human influence on events once known as "acts of God" (Marjanac, Patton, \& Thornton, 2017; McCormick et al., 2018b). The difficulty of this endeavor is highlighted by the number of pioneering or high-profile climate change cases that were dismissed based on lack of standing or because the issue was deemed non-justiciable. ${ }^{7}$ However, developments in "attribution science"- the study of the relationship between climate change and weather events and impacts-are allowing scientists to better understand the relationship between GHG emissions and extreme weather events. Research contributions include developments in the statistical methods used to quantify human influence on climate and the application of the Probabilistic Event Attribution method to quantify the contribution of human influence to specific individual weather events (Allen, 2011; Allen et al., 2007).

As a next step, scholars "translate" these scientific developments for lawyers, considering how this knowledge might alter the legal landscape and exploring the potential implications of the findings for the adjudication of climate change cases (Marjanac \& Patton, 2018). Lawsuits are beginning to draw on these advancements in climate attribution science, and courts might be more open to the notion of individual corporate responsibility for climate harm, provided that partial or contributory causation can be scientifically proven with respect to the defendant's conduct (Ganguly et al., 2018). In the appeal of the case of the Peruvian farm discussed above, Lliuya v. RWE, the Civil High Court in Hamm (Germany) provisionally accepted the plaintiff's causation arguments subject to requests for further evidence and expert opinions to be submitted at the evidentiary stage of the hearing. The Court also generally accepted climate models as valid sources of legal evidence, and concluded that the question of whether RWE's emissions are partially contributing to the endangerment of the plaintiff's hometown of Huaraz is a scientific determination.

In other cases, science is not central to the resolution of the dispute itself, but the lawsuit serves to confirm the centrality of science in decision-making processes. For instance, plaintiffs turn to the courts to ensure that agencies take into account climate change in decision-making, especially where laws or planning policies require such considerations (Wilensky, 2015). 
Despite the acknowledgement of the importance of science to climate litigation, we see two key areas that are understudied and merit further exploration. First, there is a need to investigate the production of knowledge for courts. The wider climate literature - and particularly work in the field of science and technology studies—has shown how the process of knowledge production is not a neutral or value-free process; rather, it emphasizes the role played by epistemic communities and policy networks in pushing policy (in)action (Allan, 2017; Hughes \& Romero-Lankao, 2014; Jasanoff, 2013). In climate litigation, there are examples of science being produced for the courts, both in regulatory and anti-regulatory cases. For example, Richard Heede's (2014) "Carbon Majors" was expressly developed to provide lawyers seeking to hold corporations liable with the evidence-base to legally establish the causal link between corporate activity and climate change. The research has been regarded as "a turning point in the debate about apportioning responsibility for climate change" (Starr, 2016, p. 859; see also Benjamin, 2016; Ganguly et al., 2018). In anti-regulatory cases, claims often challenge climate science or the legitimacy of climate scientists (Ley, 2018).

Second, limited attention in the climate change litigation literature has so far been given to the challenges of judges engaging with science (but see Lee, 2018 and this has been a focus in other areas of the legal literature, see, e.g., Lima, 2015; Simma, 2012 and in science and technology studies, see, e.g., Jasanoff, 2018). In law and policy making, having a baseline understanding of climate science and the capacity to engage with technical scientific material is seen as a critical foundation for the development of successful climate protection policies (Lemos, Kirchhoff, \& Ramprasad, 2012). But science often faces a higher threshold in the courtroom. In the case of San Francisco and Oakland v. Chevron, ExxonMobil, ConocoPhillips, Royal Dutch Shell, and BP (2017) before giving a decision Judge William Alsup called for a very atypical "climate change tutorial," in which a group of scientists was called to the court to answer a set of questions about climate science. To our knowledge, research in socio-legal or science and technology studies has not explored these issues in light of recent developments in climate change litigation.

\subsection{The relationship between climate litigation and human rights}

Another emerging trend in literature on climate change litigation is the growth in references to human rights. The linkages between human rights and climate change began to receive increased scholarly attention a decade ago (Averill, 2009; Knox, 2009; McInerney-Lankford, 2009) yet courts, until recently, have been reluctant to adjudicate in ways that highlight these linkages (Atapattu, 2016). However, there is a growing volume of evidence showing how the impacts of climate change affect individuals and communities in profound ways (Knox, 2009; Peel \& Osofsky, 2018; Vollmer, 2018; for a critical appraisal see Posner, 2007). In response, Peel and Osofsky (2018) in a recent article surveying key climate change cases that have included human rights claims contend that we are witnessing a "human rights turn" in climate change litigation, that is, "a trend towards petitioners increasingly employing rights claims in climate change lawsuits, and a growing receptivity of courts to this framing" (p. 40).

Rights-based climate legal action faces a number of specific challenges. The first is the "causality challenge": the need to establish a relationship between a country's or company's GHG emissions, a state's failure to implement adaptation policies, and the resulting impacts on the one hand, and the subsequent effect on human rights on the other (OHCHR, 2009; Peel \& Osofsky, 2018; Vollmer, 2018). The second, related to the discussion of time in litigation above, is the "cross-temporal challenge": the reactive nature of human rights law means that it is difficult to establish the human rights impact of climate change when it can take a significant period of time after the environmental violation for its impacts to become manifest. Claims of human rights violations are normally established immediately after actual harm has occurred, whereas in environmental law the precautionary principle accommodates potential future-focused impacts and harms (Peel \& Osofsky, 2018). Thirdly, related to the discussion of space and scales above, there is the "extra-territorial challenge": scholars have noted the difficulty of applying rights protections extraterritorially in terms of holding individuals, corporations, or governments to account for the types of harmful activities that cause effects in other states (OHCHR, 2009; Peel \& Osofsky, 2018). The final challenge to rights-based climate legal action is the potential for backlash: as scholars of human rights know all too well, the very idea of human rights is currently under scrutiny (Alston, 2017) with some even calling this "the endtimes of human rights" (Hopgood, 2013) or "the post-human rights era" (Wuerth, 2016). This questioning of the legitimacy and authority of human rights at both the national and international level adds an additional layer of complexity to rights-based climate change litigation (Vollmer, 2018).

Yet in spite of these barriers, there is some evidence to suggest that, at least in the high-profile climate change legal cases, human rights claims have had some resonance with both judges and the broader public. This trend is already observed in Urgenda Foundation v. The State of Netherlands, with the Hague Court of Appeals recognizing Urgenda's capacity to uphold plaintiffs' rights under Articles 2 and 8 of the European Convention on Human Rights (ECHR). Another ongoing and potentially important precedent could result from the investigation by the Commission on Human Rights of the Philippines to 
determine the impact of climate change on the enjoyment of human rights in the Philippines and the responsibility of the world's largest fossil fuel producers in this connection.

Scholarship has also identified a range of different explanations for the human rights turn in climate change litigation. Some legal scholars have argued that the international human rights regime is relatively robust compared to that governing international environmental law and that international environmental law claims are more likely to succeed if they can be framed as human rights claims (Bridgeman, 2003; Shelton, 2003). Framing grievances as human rights claims also opens up the potential of using other legal avenues and venues, both domestically and internationally. Social science research also shows the potential advantages of using human rights frames in climate litigation: it can render potentially abstract and distant concepts and evidence about climate change more locally relevant and personal (Limon, 2009). This also relates to the type of climate change response measures that are subject to litigation: much of the discussion about human rights claims in climate change litigation to-date has concerned those cases that address mitigation issues. There is likely to be even more fodder for those interested in the role of human rights in climate change litigation as the number of adaptation and loss and damage cases increases.

The questions of whether we are truly seeing a "rights turn" in climate litigation, and what may have caused this trend, in part depend on disciplinary and definitional perspectives as discussed above. Scholars that are analyzing legal cases and observing a rise in the number and resonance of human rights frames will answer these questions differently from law and society scholars who are interested in analyzing whether climate litigation truly has the power to shape the practice of human rights on the ground (but see Duyck et al., 2018 which covers a range of approaches). For example, Peel and Osofsky (2018) and Limon (2009) find that the Inuit petition (presented to the Inter American Commission on Human Rights in 2005) - the first high-profile attempt to use human rights norms to generate action on climate change—had "considerable impact" (Peel \& Osofsky, 2018, p. 47) because of the role the petition played in political agenda-setting at the regional and UN level. Other research, focusing on different scales, examining the impact the petition had on the Inuit community itself presents a complex picture and is more skeptical about the on-the-ground benefits of litigation (Jodoin, Snow, \& Corobow, forthcoming).

An important gap in the literature is the distance between research on climate change litigation and human rights on the one hand, and research on climate justice on the other (see, e.g., Okereke \& Coventry, 2016). The ways in which intractable issues of justice are dealt with or avoided in the international regime and at the domestic level will interact in complex ways with how climate litigation trends develop. Yet research on climate litigation has only tangentially addressed climate justice issues (but see Burkett, 2011; Duyck et al., 2018; Heiskanen, 2018; Lyster, 2016; Vollmer, 2018) and most research on climate justice has not yet turned its attention to the phenomenon of climate change litigation (but see Caney, 2005).

\section{4 | MEASURING AND EVALUATING CLIMATE LITIGATION}

As outlined in the previous sections, climate litigation has grown both quantitatively and in terms of the variety of different disciplinary and interdisciplinary perspectives brought to bear on these questions. Yet, the legal scholarship alone cannot answer many of the emerging and pressing questions around climate litigation; scholarship in other disciplines has begun to fill in some of these gaps. We identify two broad sets of issues that scholars need to be aware of in order to advance our collective understanding of the effectiveness, legitimacy, and efficacy of climate change litigation.

\section{1 | Methodological issues}

One of these concerns methodological issues. A first methodological challenge, related to the definitional problems discussed above, concerns selection bias in choosing which cases to study. This challenge manifests itself in the existing literature in a number of different ways. High-profile cases have received the lion's share of scholarly attention but we have very little sense of how generalizeable the research findings about these cases are and whether the arguments about standing, cause of action, ability to substitute for government inaction on mitigation or adaptation and so forth translate from one case to another, let alone one jurisdiction to another. There is also a risk of scholars choosing cases which support their preferred theory or argument and overlooking the counter-evidence. While there is obvious value and import in studying high-profile cases that might shape future decision-making or might be drawn on by judiciaries in other countries, scholars should also make an effort to highlight any caveats or limitations in terms of how findings might or might not "translate" to other cases or to other jurisdictions with different legal bases, procedural rules and legal cultures. For example, Peel and Osofsky (2018) identify a "rights turn" in climate litigation, but are careful to outline some of the conditions under which this model is likely to be effective when transplanted from one jurisdiction to another. Practitioners would be wise to pay attention to these caveats in the way in which they consider whether to litigate and in the ways in which they formulate their litigation strategies. This methodological point also endorses Bouwer's (2018) claim that more routine, mundane litigation merits attention. 
We would go even further to suggest that there is a pressing need to study climate legal cases that are resolved through international arbitration, as well as those that are settled before trial or before a judicial decision. A profound form of selection bias that underpins this whole area of study concerns the fact that the study of climate litigation focuses on those cases and issues that appear before a court. Commercial disputes arising from climate change regulation and adaptation have been increasingly administered by dispute resolution bodies, such as the Permanent Court of Arbitration and the International Chamber of Commerce (Miles \& Swan, 2017). Likewise, the pre-litigation stage of mobilizing the law can be enormously impactful, and has the power to shape policy and corporate activity in ways that until now have remained invisible to scholars. While studying the "shadow of law" is a challenging endeavor, it is one we would urge scholars from the fields of socio-legal studies, sociology of law, and other social sciences to take up.

Another methodological issue is practical. The existing databases are mostly limited to cases that are reported in selected jurisdictions, and which are predominantly in English, which contributes to a Global North bias in the data available. ${ }^{8}$ Furthermore, for reasons related to resource constraints, their construction often relies on self-reporting of cases or the identification of cases about which there is news coverage. This limits the possibilities for accurate large-n analysis or the making of claims about trends in climate litigation.

\subsection{Assessing impact}

The other broad set of questions this review of the literature raises concern our ability to assess the impact of cases. To date, the literature has provided very little evidence of the extent to which the growing number of cases and the development of strategies and doctrines are either driving action to address climate change or creating awareness of the issue. In part, this reflects the more general challenge of assessing the impacts of litigation beyond the courtroom, which is exacerbated by the fact that there are so many cases that are still ongoing.

Scholarship in socio-legal studies, political science and sociology offers an important foundation upon which to begin to assess the impact of cases and court decisions (Duffy, 2018; McAdam, 2017; Vanhala \& Kinghan, 2018). Two key meta-level questions concern who is responsible for defining what impact is, and how we can recognize impact when we see it. For some, the responsibility to articulate the aims of litigation and assess whether they have been achieved lies with scholars undertaking a post-hoc analysis or approaching the concept in a top-down way (Rosenberg, 2008). For others, the responsibility sits with the litigants, their lawyers, or the broader communities or movements of which they are a part and their funders (McCann, 1994). In some ways, the answers to these questions will hinge on underlying ontological and epistemological positions and attitudes towards the utility of "co-producing" research.

Whoever is asking them, these questions will likely have to address (implicitly or explicitly) the time horizon for assessing impact. Policy changes made 1 year after a high-profile case might be reversed by the next government. The political scientist Charles Epp (2009) takes the long view and examines the diffuse impacts of key legal cases across a range of policy issues over a generation. Yet, as was noted above, potential litigants might also be able to achieve the impact they were seeking through legal settlement. Scholars should clarify the time scales of their study and consider the possibility that causal processes for change might be kick-started even before litigants enter the courtroom.

The question of where to look for the impact of climate litigation will depend on the research and evaluation strategy and its epistemological approach. Impact might be found in policy and regulatory change (or lack of change). It might be found in the extent to which concern with litigation risks influences the disclosure of physical, liability, and transition risks by companies from the industrial and the financial sectors. It might also evolve media discourses surrounding the issue, in the empowerment of particular communities that have been involved in litigation, and ultimately in the profile of GHG emissions for a corporation, an industry, a municipality, a sub-state region, or a state.

Another aspect to consider is the potentially negative impacts that can result from lawsuits. For example, climate litigation that seeks compensation for losses and damages arising from climate change effects can inflict substantial losses on the balance sheets of defendants. Litigation could also inflict reputational damage, which is particularly harmful in financial markets (Armour et al., 2016). To avoid potential losses, the prospect of climate litigation could disincentivise investments in polluting projects. But the prospect of climate litigation could also desincentivse investments in "climate-friendly" technologies if investors identify a too high risk of being challenged when such technologies fail to have the impact that borrowers committed to. Another example is the numerous legal challenges to wind farms by local communities. Consequently, climate litigation could hinder the development of mitigation and adaptation projects (Allen, 2018). There is also evidence from political science to suggest that litigation can result in broader political backlash which defeats the original aim of the litigants (Keck, 2009; Rosenberg, 2008). These ambiguities cast doubt over the desirability and efficacy of pursuing climate justice through the courts. They provide a counterbalance to the current academic literature, which emphasizes the potential of climate litigation to accelerate the transition to a low-carbon economy and describes climate litigation as a means to tackle the inequalities resulting from climate change, for example by empowering affected communities. 
Demonstrating impact-however it is defined-requires painstaking research work in terms of establishing the causal chains between a legal case on the one hand, and the different forms of impact on the other. This work also has to address alternative explanations that might account for the change but that lie outside of the legal case. One method for establishing causality is through the use of advanced techniques in quantitative analysis, but this has proven difficult in the study of climate litigation for some of the reasons identified in the section above. Another method that may be more fruitful but has thus far been deployed in only a handful of studies is the use of process tracing - a qualitative technique that offers a framework for analyzing causal relationships between antecedents and outcomes (Bennett \& Checkel, 2014; Vanhala, 2017 and see for examples Jodoin et al., forthcoming, Vanhala \& Hestbaek, 2016).

While some funders of climate litigation are starting to evaluate their grant-making strategies in regards to climate litigation, thinking in this area is still relatively embryonic and advances in thinking are not widely shared. Literature on strategic philanthropy and public interest litigation more generally might offer a useful starting point for thinking about these issues (Cummings \& Rhode, 2009).

\section{5 | CONCLUSION}

This review has examined trends and critical questions in the climate change litigation literature. It is worth noting that the relationship between trends in litigation and trends in the literature is unclear. Because of the various difficulties in identifying and tracking climate change cases and the lack of consistent cross-jurisdictional data on climate-relevant cases we cannot know (and we would argue that in many ways it does not matter) whether the literature is a mirror to the litigation activity out in the world. What we do know is that over the past 20 years, courts around the world have been increasingly engaged in debates about the causes and consequences of climate change. Scholars have, in turn, developed a flourishing body of literature on the phenomenon. The systematic search confirms the growth in the volume of research and the growing interest among scholars in disciplines beyond law in this area of study. It also highlights the fact that, until recently, research has been focused on a limited set of jurisdictions and has placed disproportionate emphasis on certain actors and specific aspects of the climate agenda. The research trajectories and the key themes identified in this review are the result of our assessment of the most potentially fruitful ways forward.

The review suggests that scholars have provided several insights into why litigants use the courts to address climate change, and the main challenges in selected jurisdictions or on specific topics. Despite these valuable insights, this review has also demonstrated some gaps that remain in our current understanding of climate litigation, opening up horizons for future research. The first, and perhaps most fundamental, is that of evaluating the impact of both regulatory and anti-regulatory climate-related lawsuits. The second, related issue is that to-date the research has focused primarily on small numbers of highprofile cases concentrated in North America, Europe and Australia. As a growing number of cases emerge in other countries - particularly in the Global South — and involving a wider range of actors-such as scientists, cities, funders and financiers-, the evidence base must also diversify. Third, despite some notable exceptions, research on climate litigation is still primarily dominated by legal scholars. The engagement of socio-legal scholars and researchers in political science, sociology, and anthropology should help reveal different angles. In particular, there is a need to engage more thoroughly with the scales and time frames involved in climate litigation, as well as with debates over the extent to which courts are and/or should be a part of systems of polycentric governance.

Addressing these issues and questions will help to develop a deeper understanding of the extent to which litigation is a tool to strengthen climate governance (or to understand how litigation, under some conditions, may undermine governance efforts). For instance, litigation may develop into a decentralized mechanism to enforce the Paris Agreement at national and subnational scales. Moreover, by signaling the strength of civil society's mobilization around this issue, it may change the expectations of firms and investors regarding the political and legal risks of inaction. The adjudication of climate change has the potential to shape norms and beliefs in the broader population regarding the salience of climate change and the responsibility of different actors but it may also provoke a judicial or popular backlash. And finally, it may (or may not) lead to new legal rules redefining responsibilities and liability in the context of globalized externalities that are unequally generated and have unequal impacts across and within borders.

\section{ACKNOWLEDGMENTS}

We would like to thank Michai Robertson and Serena Cavasin for their excellent research assistance and to Corin Throsby for editorial support. We are also grateful to the anonymous reviewers, the editor and Lisa Benjamin, Chris Hilson, Sébastien Jodoin, Maria Lee, Annalisa Savaresi, and Steven Vaughan for very helpful comments which helped to improve this manuscript greatly. Any remaining errors or omissions are our own. Joana Setzer acknowledges the 
financial support of the British Academy through the Postdoctoral Fellowship, as well as the Grantham Foundation for the Protection of the Environment and the ESRC via the Centre for Climate Change Economics and Policy. Lisa Vanhala acknowledges the financial support of the ESRC through the Future Research Leaders Grant (grant number: ES/K008153/1) and the European Research Council through the Starting Grant programme (CCLAD Starting Grant (StG), SH2, ERC-2017-STG).

\section{CONFLICT OF INTEREST}

The authors have declared no conflicts of interest for this article.

\section{ENDNOTES}

${ }^{1}$ Cases addressing adaptation or loss and damage may not make explicit use of these terms which are the terms used in the United Nations regime. However, in some instances tort cases are addressing damages and losses caused by climate change impacts and could be categorized as "loss and damage" cases.

${ }^{2}$ While our approach offers a relatively thorough survey of the literature, a complete assessment of all publications would involve a search of related terms—such as "climate" and/or "climate change" and "courts," "liability," "lawsuit," "atmospheric trust litigation," "tort law" and/or "adjudication"-in the full text of articles as well as in the title and abstract. It would also include books, book chapters and a wider spectrum of journals and publications that are not identified by the search engines. We use this conservative approach as a starting point but the literature we discuss in the article is much broader than those articles identified through the systematic approach.

${ }^{3}$ See the U.S. climate litigation database maintained by the Sabin Center for Climate Change Law, in collaboration with Arnold \& Porter Kaye Scholer LLP: http://climatecasechart.com/us-climate-change-litigation.

${ }^{4}$ See the Climate Change Litigation of the World database, jointly produced by the Sabin Center for Climate Change Law and the Grantham Research Institute on Climate Change and the Environment at the London School of Economics: http://www. lse.ac.uk/GranthamInstitute/climate-change-laws-of-the-world.

${ }^{5}$ The Paris Agreement was adopted at the Conference of the Parties to the UNFCCC on December 12, 2015, and came into force on November 4, 2016.

${ }^{6} \mathrm{NDCs}$ are national climate plans highlighting climate actions, including climate related targets, policies and measures governments aims to implement in response to climate change and as a contribution to global climate action.

${ }^{7}$ Such as, for example, Kivalina v. ExxonMobil, 663 FSupp 2d 863 (ND Cal September 20, 2009); Native Village of Kivalina v. ExxonMobil Corp, 696F 3d 849, 854 (ninth Cir 2012) and California v. General Motors Corporation, et al., 2007 WL 272871 (ND Cal, September 17, 2007), where it was held that a public nuisance claim against major GHG emitters for contributing to climate change was non-justiciable.

${ }^{8}$ See notes 3 and 4 above for details of the databases.

\section{ORCID}

Joana Setzer (10 https://orcid.org/0000-0002-7705-7684

Lisa C. Vanhala (10 https://orcid.org/0000-0003-4886-0061

\section{FURTHER READING}

Christoff, P. (2016). The promissory note: COP 21 and the Paris Climate agreement. Environmental Politics, 25(5), 765-787. https://doi.org/10.1080/09644016.2016. 1191818

Gerrard, M. B., \& Wilensky, M. (2016). The role of the national courts in GHG emissions reductions. In D. A. Farber \& M. Peeters (Eds.), Climate change law (pp. 359-376). Cheltenham, England: Edward Elgar.

Hoffmann, M. J. (2011). Climate governance at the crossroads: Experimenting with a global response. Oxford, England: Oxford University Press.

International Bar Association (IBA). (2014). Achieving justice and human rights in an era of climate disruption. Climate change justice and human rights task force report. Retrieved from https://www.ibanet.org/PresidentialTaskForceClimateChangeJustice2014Report.aspx

Savaresi, A. (2016). The Paris agreement: A new beginning? Journal of Energy \& Natural Resources Law, 34(1), 16-26. https://doi.org/10.1080/02646811.2016. 1133983

Van Renssen, S. (2016). Courts take on climate change. Nature Climate Change, 6, 655-656. https://doi.org/10.1038/nclimate3067 


\section{REFERENCES}

Abbott, K. W. (2014). Strengthening the transnational regime complex for climate change. Transnational Environmental Law, 3(1), 57-88. https://doi.org/10.1017/ S2047102513000502

Adler, D. (2018). US climate change litigation in the age of Trump: Year one. Sabin Center for Climate Change Law Working Paper (February 2018). Retrieved from http://columbiaclimatelaw.com/files/2018/02/Adler-2018-02-U.S.-Climate-Change-Litigation-in-the-Age-of-Trump-Year-One.pdf

Allan, B. B. (2017). Producing the climate: States, scientists, and the constitution of global governance objects. International Organization, 71(1), 131-162. https:// doi.org/10.1017/S0020818316000321

Allen, M. (2011). The scientific basis for climate change liability. In R. Lord, S. Goldberg, L. Rajamani, \& J. Brunnée (Eds.), Climate change liability: Transnational law and practice (pp. 8-22). Cambridge, MA: Cambridge University Press. https://doi.org/10.1017/CBO9781139084383.004

Allen, K. (2018). Strict US market rules limit corporate sellers of green bonds. Financial Times. Retrieved from https://www.ft.com/content/baa217c4-157c-11e8-9376$4 \mathrm{a} 6390 \mathrm{addb} 44$

Allen, M. R., Pall, P., Stone, D. A., Scott, P., Frame, D. J., Min, S.-K., ... Yukimoto, S. (2007). Scientific challenges in the attribution of harm to human influence on climate. Pennsylvania Law Review, 155(6), 1353-1400.

Alston, P. (2017). The populist challenge to human rights. Journal of Human Rights Practice, 9(1), 1-15. https://doi.org/10.1093/jhuman/hux007

Andersen, E. (2005). Out of the closets and into the courts: Legal opportunity structure and gay rights litigation. Ann Arbor, MI: University of Michigan Press.

Andonova, L. B., Betsill, M. M., \& Bulkeley, H. (2009). Transnational climate governance. Global Environmental Politics, 9(2), 52-73. https://doi.org/10.1162/ glep.2009.9.2.52

Armour, J., Awrey, D., Davies, P., Enriques, L., Gordon, J. N., Mayer, C., \& Payne, J. (2016). Principles of financial regulation. Oxford, England: Oxford University Press.

Atapattu, S. (2016). Human rights approaches to climate change: Challenges and opportunities. London, England: Routledge.

Averill, M. (2008). Climate litigation: Ethical implications and societal impacts. Denver University Law Review, 85(4), 899-918.

Averill, M. (2009). Linking climate litigation and human rights. Review of European Community \& International Environmental Law, 18, 139-147. https:// doi.org/10.1111/j.1467-9388.2009.00636.x

Bartel, R., McFarland, R., \& Hearfield, C. (2014). Taking a de-binarised envirosocial approach to reconciling the environment vs economy debate: Lessons from climate change litigation for planning in NSW, Australia. The Town Planning Review, 85(1), 67-96. https://doi.org/10.3828/tpr.2014.6

Benjamin, L. (2016). The responsibilities of carbon major companies: Are they (and is the law) doing enough? Transnational Environmental Law, 5(2), 353-378. https://doi.org/10.1017/S2047102516000194

Benjamin, L. (2017). The duty of due consideration in the Anthropocene: Climate risk and English directorial duties. Carbon Climate Law Review, 2, 90-99. https:// doi.org/10.21552/cclr/2017/2/5

Benjamin, L. (2018). Institutional investors and carbon major companies: Private environmental governance post-paris. George Washington Journal of Energy and Environmental Law, 9(1), 5-20.

Bennett, A., \& Checkel, J. (Eds.). (2014). Process tracing: From metaphor to analytic tool (strategies for social inquiry). Cambridge, England: Cambridge University Press. https://doi.org/10.1017/CBO9781139858472

Bergkamp, L. (2015). Adjudicating scientific disputes in climate science: The limits of judicial competence and the risks of taking sides. Environmental Liability, 3, 80102. http://doi.org/10.2139/ssrn.2679252

Bergkamp, L., \& Hanekamp, J. C. (2015). Climate change litigation against states: The perils of court-made climate policies. European Energy and Environmental Law Review, 24(5), 102-114.

Bergkamp, L., \& Stone, S. J. (2015). The Trojan horse of the Paris agreement on climate change: How multi-level, non-hierarchical governance poses a threat to constitutional government. Environmental Liability, 4, 119-140. https://doi.org/10.2139/ssrn.2715145

Biniaz, S. (2017). Act locally, reflect globally: A checklist of options for U.S. cities and states to engage internationally in climate action. Sabin Center for Climate Change Law Paper. Retrieved from http://columbiaclimatelaw.com/files/2017/05/Biniaz-May_2017-Act-Locally-Reflect-Globally-.pdf

Blumm, M., \& Wood, M. (2015). No ordinary lawsuit': Climate change, due process, and the public trust doctrine. The American University Law Review, 67(1), 1-87.

Bodansky, D. (2017). The role of the international court of justice in addressing Climate Change: Some preliminary reflections. Arizona State Law Journal, 49(Special Issue), 689-712.

Bogojević, S. (2013). EU Climate Change litigation. Law \& Policy, 35, 184-207. https://doi.org/10.1111/lapo.12005

Bouwer, K. (2015, 22 May). Climate consciousness in daily legal practice. OUPblog. Retrieved from https://blog.oup.com/2015/05/climate-consciousness-daily-legalpractice/

Bouwer, K. (2018). The unsexy future of climate change litigation. Journal of Environmental Law, 30(3), 483-506. https://doi.org/10.1093/jel/eqy017

Bridgeman, N. L. (2003). Human rights litigation under the ATCA as a proxy for environmental claims. Yale Human Rights and Development Law Journal, 6(1), 1-44

Bulkeley, H., Andonova, L. B., Betsill, M., Compagnon, D., Hale, T., Hoffman, M. J., ... Roger, C. (2014). Transnational climate change governance. Cambridge, MA: Cambridge University Press.

Bulkeley, H., \& Betsill, M. (2005). Rethinking sustainable cities: Multilevel governance and the 'urban' politics of climate change. Environmental Politics, 14(1), 42-63. https://doi.org/10.1080/0964401042000310178

Burger, M., Gundlach, J., Kreilhuber, A., Ognibene, L., Kariuki, A., \& Gachie, A. (2017). The status of climate change litigation. A global review. New York, NY: United Nations Environment Programme.

Burkett, M. (2011). Climate justice and the elusive climate tort. Yale Law Journal Online, 121(115). Retrieved from http://yalelawjournal.org/forum/climate-justice-andthe-elusive-climate-tort

Burns, W. C. G., \& Osofsky, H. M. (Eds.). (2009). Adjudicating Climate Change-State, national and international approaches. Cambridge, MA: Cambridge University Press.

Butterfield, B. (2018). The potential role of climate change litigation in furthering the mitigation objectives of the Paris agreement. Asia Pacific Journal of Environmental Law, 21, 29-49. https://doi.org/10.4337/apjel.2018.01.02

Caney, S. (2005). Cosmopolitan justice, responsibility, and global Climate Change. Leiden Journal of International Law, 18(4), 747-775. https://oi.org/10.1017/ S0922156505002992

Carlarne, C. (2010). Climate law and policy in the EU and the US. Oxford, England: Oxford University Press.

Carney, M. (2018). A transition in thinking and action. Remarks given by Mark Carney, Governor of the Bank of England International Climate Risk Conference for Supervisors, De Nederlandsche Bank, Amsterdam, April 6, 2018. Retrieved from https://www.bankofengland.co.uk/-/media/boe/files/speech/2018/a-transition-inthinking-and-action-speech-by-mark-carney.pdf

Carnwath, J. S. C. (2016). Climate change adjudication after Paris: A reflection. Journal of Environmental Law, 28(1), 5-9. https://doi.org/10.1093/jel/eqw009

ClientEarth. (2018, 20 August). A survey of UK attitudes towards climate change and its impacts. Retrieved from https://www.documents.clientearth. org/library/download-info/clientearths-climate-snapshot/ 
Coglianese, G. (1996). Litigating within relationships: Disputes and disturbance in the regulatory process. Law and Society Review, 30(4), 735-765. https:// doi.org/10.2307/3054116

Colares, J. F., \& Ristovski, K. (2014). Pleading patterns and the role of litigation as a driver of Federal Climate Change Legislation. Jurimetrics, 54(4), 329-373. Retrieved from http://www.jstor.org/stable/24395696

Cox, R. (2016). A climate change litigation precedent: Urgenda Foundation v The State of The Netherlands. Journal of Energy \& Natural Resources Law, 34(2), 143-163. https://doi.org/10.1080/02646811.2016.1147887

Cummings, S., \& Rhode, D. (2009). Public interest litigation: Insights from theory and practice. Fordham Urban Law Journal, 36(4), 603-651.

de Graaf, K. J., \& Jans, J. H. (2015). The Urgenda decision: Netherlands liable for role in causing dangerous global climate change. Journal of Environmental Law, 27 (3), 517-527. https://doi.org/10.1093/jel/eqv030

Divisek, P. (2011). Climate change torts: American electric power Connecticut. Macquarie Journal of International and Comparative Environmental Law, 7(1), $108-110$.

Doherty, B., \& Hayes, G. (2011). Having your day in court: Judicial opportunity and tactical choice in anti-GMO campaigns in France and the United Kingdom. Comparative Political Studies, 47(1), 3-29. https://doi.org/10.1177/0010414012439184

Duffy, M. (2018). Australian private securities class actions and public interest: Assessing the 'private attorney-general' by reference to the rationales of public enforcement. Australian Journal of Corporate Law, 32(2), 162-193.

Dumas, M. (2017). Taking the law to court: Citizen suits and the legislative process. American Journal of Political Science, 61(4), 944-957. https://doi.org/10.1111/ ajps. 12302

Duyck, S., Jodoin, S., \& Johl, A. (Eds.). (2018). Routledge handbook of human rights and climate governance. London, New York: Routledge.

Eisenstat, F. (2011). American Electric Power Co. v. Connecticut: How one less legal theory available in the effort to curb emissions is actually one step forward for the cause. Tulane Environmental Law Journal, 25(1), 221-230.

Epp, C. R. (1998). The rights revolution: Lawyers, activists, and supreme courts in comparative perspective. Chicago, IL: University of Chicago Press.

Epp, C. R. (2009). Making rights real: Activists, bureaucrats, and the creation of the legalistic state. Chicago, IL: University of Chicago Press.

Falkner, R. (2016). The Paris agreement and the new logic of international climate politics. International Affairs, 92(5), 1107-1125. https://doi.org/10.1111/1468-2346. 12708

Faure, M. G., \& Nollkaemper, A. (2007). International liability as an instrument to prevent and compensate for Climate Change. Stanford Journal of International Law, $26,123-180$.

Ferreira, P. (2016). 'Common but differentiated responsibilities' in the National Courts: Lessons from Urgenda v. The Netherlands. Transnational Environmental Law, 5(2), 329-351. https://doi.org/10.1017/S2047102516000248

Fisher, E. (2013). Climate change litigation, obsession and expertise: Reflecting on the scholarly response to Massachusetts v. EPA. Law \& Policy, 35(3), 236-260. https://doi.org/10.1111/lapo.12006

Fisher, E., Scotford, E., \& Barritt, E. (2017). The legally disruptive nature of climate change. Modern Law Review, 80(2), 173-201. https://doi.org/10.1111/1468-2230. 12251

Flynn, J. (2012). Climate of confusion: Climate Change litigation in the wake of American electric power v. Connecticut. Georgia State University Law Review, 29(3), 823-864.

Franta, B. (2017). Litigation in the fossil fuel divestment movement. Law \& Policy, 39(4), 393-411. https://doi.org/10.1111/lapo.12086

Frumhoff, P. C., Heede, R., \& Oreskes, N. (2015). The climate responsibilities of industrial carbon producers. Climatic Change, 132(2), 157-171. https:// doi.org/10.1007/s10584-015-1472-5

Galanter, M. (1974). Why the "haves" come out ahead: Speculations on the limits of legal Change. Law and Society Review, 9(1), 95-160. https:// doi.org/10.2307/3053023

Ganguly, G., Setzer, J., \& Heyvaert, V. (2018). If at first you Don't succeed: Suing corporations for climate change. Oxford Journal of Legal Studies, $38,841-868$. https://doi.org/10.1093/ojls/gqy029

Gerrard, M., \& Freeman, J. (2007). Global climate change and U.S. law. Chicago: American Bar Association.

Ghaleigh, N. S. (2010). 'Six honest serving men': Climate change litigation as legal mobilization and the utility of typologies. Climate Law, 1(1), 31-61.

Giddens, A. (2009). Politics of climate change. London, England: Polity Press.

Grain. (2018, July). Emissions impossible: How big meat and dairy are heating up the planet. Retrieved from https://www.grain.org/article/entries/5976-emissionsimpossible-how-big-meat-and-dairy-are-heating-up-the-planet

Grossman, D. A. (2003). Warming up to a not-so-radical idea: Tort-based climate change litigation. Columbia Journal of Environmental Law, $28,1$.

Gupta, J. (2007). Legal steps outside the Climate convention: Litigation as a tool to address climate change. Review of European Community \& International Environmental Law, 16, 76-86. https://doi.org/10.1111/j.1467-9388.2007.00541.x

Haines, F., \& Reichman, N. (2008). The problem that is global warming: Introduction. Law \& Policy, 30(4), 385-393. https://doi.org/10.1111/j.1467-9930.2008. 00288.x

Harrington, J. (2007). Climate change, human rights and the right to be cold. Fordham Environmental Law Review, 18(3), 513-536.

Harrison, K., \& Sundstrom, L. (Eds.). (2010). Global commons, domestic decisions: The comparative politics of climate change. Cambridge, MA: MIT Press.

Hayes, G. (2013). Negotiating proximity: Expert testimony and collective memory in the trials of environmental activists in France and the United Kingdom. Law \& Policy, 35(3), 208-235. https://doi.org/10.1111/lapo.12004

He, X. (2018). Legal and policy pathways of climate change adaptation: Comparative analysis of the adaptation practices in the United States, Australia and China. Transnational Environmental Law, 7(2), 347-373. https://doi.org/10.1017/S2047102518000092

Heede, R. (2014). Tracing anthropogenic carbon dioxide and methane emissions to fossil fuel and cement producers, 1854-2010. Climatic Change, 122(1-2), 229-241. https://doi.org/10.1007/s10584-013-0986-y

Heiskanen, H. P. (2018). Climate change and the European court of human rights. In Routledge handbook of human rights and Climate governance (pp. 319-324) Lonon, New York: Routledge.

Hilson, C. (2002). New social movements: The role of legal opportunity. Journal of European Public Policy, 9(2), 238-255. https:// doi.org/10.1080/13501760110120246

Hilson, C. J. (2010). Climate change litigation: An explanatory approach (or bringing grievance back in). In F. Fracchia \& M. Occhiena (Eds.), Climate change: la risposta del diritto (pp. 421-436). Napoli: Editoriale Scientifica.

Hilson, C. J. (2012). UK climate change litigation: between hard and soft framing. In S. Farrall, T. Ahmed, \& D. French (Eds.), Criminological and legal consequences of climate change. Oxford: Hart 2010.

Hilson, C. J. (2018). Framing time in climate change litigation. Oñati Socio-Legal Series. Retrieved from https://papers.ssrn.com/sol3/papers.cfm?abstract_id=3179384

Hilson, C. J. (2019). Climate change litigation and the narrative turn: Law, courts and populism. In S. Sterett \& L. E. Walker (Eds.), Research handbook on law and courts. Cheltenham, England: Edward Elgar. 
Hinteregger, M. (2017). Civil liability and the challenges of climate change: A functional analysis. Journal of European Tort Law, (2), 238-259. https://doi.org/ 10.1515/jetl-2017-0010

Hodas, D. R. (2000). Standing and climate change: Can anyone complain about the weather? Journal of Transnational Law \& Policy, 9(supplement Issue), 451-486. Hopgood, S. (2013). The endtimes of human rights. Ithaca, NY: Cornell University Press.

Hsu, S.-L. (2008). A realistic evaluation of climate change litigation through the lens of a hypothetical lawsuit. University of Colorado Law Review, 79(3), 701-766.

Hughes, S., \& Romero-Lankao, P. (2014). Science and institution building in urban climate-change policymaking. Environmental Politics, 23(6), 1023-1042. https:// doi.org/10.1080/09644016.2014.921459

Humby, T.-L. (2018). The Thabametsi case: Case no 65662/16 Earthlife Africa Johannesburg v Minister of Environmental Affairs. Journal of Environmental Law, 30 (1), 145-155. https://doi.org/10.1093/jel/eqy007

Humphreys, S. (2009). Human rights and climate change. Cambridge, MA: Cambridge University Press.

IPCC. (2018). Global warming of $1.5^{\circ} \mathrm{C}$-Summary for policymakers. Retrieved from http://report.ipcc.ch/sr15/pdf/sr15_spm_final.pdf

Jasanoff, S. (1995). Science at the bar: Law, science, and technology in America. Cambridge, MA: Harvard University Press.

Jasanoff, S. (2013). A world of experts: Science and global environmental constitutionalism. Environmental Affairs Law Review, 40(2), 439-452.

Jasanoff, S. (2018). Science, common sense \& judicial power in US courts. Daedalus, 147(4), 15-27. https://doi.org/10.1162/daed_a_00517.

Jodoin, S., Snow, S. \& Corobow, A. (forthcoming). Realizing the right to be cold? Tracing the impact of the 2005 Inuit petition on human rights and climate justice.

Jordan, A., Huitema, D., Van Asselt, H., \& Forster, J. (Eds.). (2018). Governing climate change: Polycentricity in action? Cambridge, MA: Cambridge University Press. https://doi.org/10.1017/9781108284646.

Keck, T. (2009). Beyond backlash: Assessing the impact of judicial decisions on LGBT rights. Law and Society Review, 43(1), 158-186. https://doi.org/10.1111/ j.1540-5893.2009.00370.x

Keele, D. M. (2018). Climate change litigation and the national environmental policy act. Journal of Environmental Law, 30(2), 285-309. https://doi.org/10.1093/ jel/eqx030

Keohane, R. O., \& Victor, D. G. (2011). The regime complex for climate change. Perspectives on Politics, 9(1), 7-23. https://doi.org/10.1017/S1537592710004068

Knox, J. (2009). Climate change and human rights law. Virginia Journal of International Law, 50(1), 163-218.

Kysar, D. (2011). What climate change can do about tort law. Environmental Law, 41(1), 1-71.

Kysar, D. (2018). The public life of private law: Tort law as a risk regulation mechanism. European Journal of Risk Regulation, 9(1), 48-65. https://doi.org/10.1017/ err. 2017.79

Lee, M. (2018). The sources and challenges of norm generation in tort law. European Journal of Risk Regulation, 9(1), 34-47. https://doi.org/10.1017/err.2017.76

Lemos, M. C., Kirchhoff, C. J., \& Ramprasad, V. (2012). Narrowing the climate information usability gap. Nature Climate Change, 2, 789-794. https:// doi.org/10.1038/nclimate1614

Ley, A. J. (2018). Mobilizing doubt: The legal mobilization of Climate denialist groups. Law \& Policy, 40(3), 221-242. https://doi.org/10.1111/lapo.12103

Lima, L. C. (2015). The evidential weight of experts before the ICJ: Reflections on the whaling in the Antarctic case. Journal of International Dispute Settlement, 6(3), 621-635. https://doi.org/10.1093/jnlids/idv022

Limon, M. (2009). Human rights and climate change: Constructing a case for political action. Harvard Environmental Law Review, $33(2), 439-476$.

Lin, J. (2012). Climate change and the courts. Legal Studies, 32, 35-57. https://doi.org/10.1111/j.1748-121X.2011.00206.X

Lin, J. (2015). Climate change litigation in Asia and the Pacific. In G. van Calster, W. Vandenberghe, \& L. Reins (Eds.), Research handbook on climate change mitigation law. Cheltenham, England: Edward Elgar.

Lord, R., Goldberg, S., Rajamani, L., \& Brunnée, J. (2011). Climate change liability: Transnational law and practice. Cambridge: Cambridge University Press.

Lyster, R. (2016). Climate justice and disaster law. Cambridge, MA: Cambridge University Press.

Manus, P. (2014). Kivalina at the supreme court: A lost opportunity for federal common law. Pittsburgh Journal of Environmental and Public Health Law, 8(2), $223-288$.

Marjanac, S., \& Patton, L. (2018). Extreme weather event attribution science and climate change litigation: An essential step in the causal chain? Journal of Energy \& Natural Resources Law, 36, 265-298. https://doi.org/10.1080/02646811.2018.1451020

Marjanac, S., Patton, L., \& Thornton, J. (2017). Acts of God, human influence and litigation. Nature Geoscience, 10, 616-619. https://doi.org/10.1038/ngeo3019

Markell, D. L., \& Ruhl, J. B. (2010). An empirical survey of climate change litigation in the United States. FSU College of Law, Business \& Economics. Public Law Research Paper, 433, 10644-10655. https://doi.org/10.2139/ssrn.1585341

Markell, D. L., \& Ruhl, J. B. (2012). An empirical assessment of climate change in the courts: A new jurisprudence or business as usual? Florida Law Review, 64(1), 15-86.

Mayer, B. (2014). State responsibility and climate change governance: A light through the storm. Chinese Journal of International Law, 13(3), 539-575. https://doi.org/ 10.1093/chinesejil/jmu030

McAdam, D. (2017). Social movement theory and the prospects for climate change activism in the United States. Annual Review of Political Science, 20, 189-208. https://doi.org/10.1146/annurev-polisci-052615-025801

McCann, M. (1994). Rights at work: Pay equity reform and the politics of legal mobilization. Chicago, IL: University of Chicago Press.

McCormick, S., Simmens, S. J., Glicksman, R., Paddock, L., Kim, D., \& Whited, B. (2018a). The role of health in climate litigation. American Journal of Public Health, 108(2), S104-S108.

McCormick, S., Simmens, S. J., Glicksman, R. L., Paddock, L., Kim, D., Whited, B., \& Davies, W. (2018b). Science in litigation, the third branch of U.S. Climate Policy. Science, 357(6355), 979-980.

McGinnis, M. D. (2015). Polycentric governance in theory and practice: Dimensions of Aspiration and Practical Limitations. Prepared for Ostrom Workshop, 14 December 2015. Bloomington, IN: Indiana University Bloomington.

McInerney-Lankford, S. (2009). Climate Change and human rights: An introduction to legal issues. Harvard Environmental Law Review, 33, 431.

Melnick, R. S. (1983). Regulation and the courts: The case of the clean air act. Washington, DC: Brookings Institution Press.

Michaelowa, A. (2007). Environmental progress through litigation? Climate Policy, 7(6), 543-544. https://doi.org/10.1080/14693062.2007.9685677

Michaelowa, K., \& Michaelowa, A. (2017). Transnational climate governance initiatives: Designed for effective climate change mitigation? International Interactions, 43(1), 129-155. https://doi.org/10.1080/03050629.2017.1256110

Miles, W. J., \& Swan, N. K. (2017). Climate change and dispute resolution. Dispute Resolution International, 11(2), 117-132.

Millner, F., \& Ruddock, K. (2011). Climate litigation: Lessons learned and future opportunities. Alternative Law Journal, 36(1), 27-32. https:// doi.org/10.1177/1037969X1103600106

Nachmany, M., \& Setzer, J. (2018). Policy brief global trends in climate change legislation and litigation: 2018 snapshot. Grantham Research Institute on Climate Change and the Environment. Retrieved from http://www.lse.ac.uk/GranthamInstitute/wp-content/uploads/2018/04/Global-trends-in-climate-change-legislation-andlitigation-2018-snapshot-3.pdf

Nosek, G. (2018). Climate change litigation and narrative: How to use litigation to tell compelling climate stories. William \& Mary Environmental Law and Policy Review, 42, 733-783. 
Nyinevi, C. (2015). Universal civil jurisdiction: An option for global justice in climate change litigation. Journal of Politics and Law, 8(3), 135-148.

O'Donnell, T. (2016). Legal geography and coastal climate change adaptation: The Vaughan litigation. Geographical Research, 54, 301-312. https:// doi.org/10.1111/1745-5871.12170

OHCHR. (2009). Report of the Office of the United Nations High Commissioner for human rights on the relationship between climate change and human rights (UN Doc. A/HRC/10/61), 15 January 2009.

Okereke, C., \& Coventry, P. (2016). Climate justice and the international regime: Before, during, and after Paris. WIREs Climate Change, 7(6), 834-851. https:// doi.org/10.1002/wcc.419

Okonkwo, T. (2017). Protecting the environment and people from climate change through climate change litigation. Journal of Politics and Law, 10(5), 66-77. https:// doi.org/10.5539/jpl.v10n5p66

Osofsky, H. M. (2005a). The geography of climate change litigation: Implications for transnational regulatory governance. Washington University Law Quarterly, 83 (6), 1789-1856.

Osofsky, H. M. (2005b). Complexities of addressing the impacts of climate change on indigenous peoples through international law petitions: A case study of the Inuit petition to the Inter-American Commission on Human Rights. In R. S. Abate \& E. A. Kronk (Eds.), Climate change and indigenous peoples: The search for legal remedies. Cheltenham, England: Edward Elgar.

Osofsky, H. M. (2007a). Local approaches to transnational corporate responsibility: Mapping the role of subnational climate change litigation. Pacific McGeorge Global Business Development Law Journal, 20(1), 143-160.

Osofsky, H. M. (2007b). The intersection of scale, science, and law in Massachusetts v. EPA. Proceedings of the Annual Meeting (American Society of International Law), 101, 61-65. https://doi.org/10.1017/S0272503700025180

Osofsky, H. M. (2010). The continuing importance of climate change litigation. Climate Law, 1, 3-29. https://doi.org/10.3233/CL-2010-002

Osofsky, H. M., \& Peel, J. (2013). The role of litigation in multilevel Climate Change governance: Possibilities for a lower carbon future? Environmental and Planning Law Journal, 30, 303. Retrieved from https://ssrn.com/abstract=2523994

Ostrom, E. (2009). A polycentric approach for coping with climate change (World Bank Policy Research Working Paper Series no. 5095). Retrieved from http:// ssrn.com/abstract $=1494833$

Ostrom, E. (2010). Polycentric systems for coping with collective action and global environmental change. Global Environmental Change, 20(4), 550-557. https:// doi.org/10.1016/j.gloenvcha.2010.07.004

Peel, J. (2007). The role of Climate Change litigation in Australia's response to global warming. University of Melbourne Legal Studies Research Paper No. 269. Environmental and Planning Law Journal, 24(2), 90-105.

Peel, J. (2011). Issues in climate change litigation. Carbon and Climate Law Review, 5(1), 15-24. https://doi.org/10.21552/CCLR/2011/1/162

Peel, J., Godden, L., \& Keenan, R. (2012). Climate change law in an era of multi-level governance. Transnational Environmental Law, 1(2), 245-280. https:// doi.org/10.1017/S2047102512000052

Peel, J., \& Lin, J. (2018). Transnational climate litigation: the contribution of the Global South. Work-in-progress draft presented at the American Society of International Law Mid-Year Research Forum, November 9-10, 2018 (copy on file with authors).

Peel, J., \& Osofsky, H. M. (2013). Climate change litigation's regulatory pathways: A comparative analysis of the United States and Australia. Law \& Policy, 35(3), 150-183. https://doi.org/10.1111/lapo.12003

Peel, J., \& Osofsky, H. M. (2015). Climate change litigation regulatory pathways to cleaner energy. Cambridge, MA: Cambridge University Press.

Peel, J., \& Osofsky, H. M. (2018). A rights turn in climate change litigation? Transnational Environmental Law, 7(1), 37-67. https://doi.org/10.1017/ S2047102517000292

Peeters, M. (2016). Urgenda foundation and 886 individuals v. The State of The Netherlands: The dilemma of more ambitious greenhouse gas reduction action by EU member states. Review of European, Comparative \& International Environmental Law, 25(1), 123-129. https://doi.org/10.1111/reel.12146

Posner, E. (2007). Climate Change and international human rights litigation: A critical appraisal. University of Pennsylvania Law Review, 155(6), 1925-1946.

Preston, B. J. (2009). Climate change litigation. Journal of the Judicial Commission of New South Wales, 9(2), 205-236.

Preston, B. J. (2011a). Climate change litigation (part 1). Carbon \& Climate Law Review, 5(1), 3-14.

Preston, B. J. (2011b). Climate change litigation (part 2). Carbon \& Climate Law Review, 2, 244-263.

Preston, B. J. (2016a). The contribution of the courts in tackling climate change. Journal of Environmental Law, 28(1), 11-17. https://doi.org/10.1093/jel/eqw004

Preston, B. J. (2016b). The role of the courts in facilitating climate change adaptation. The Asia-Pacific Centre for Environmental Law Climate Change Adaptation Platform. Retrieved from https://ssrn.com/abstract=2829287

Rajamani, L. (2007). Public interest environmental litigation in India: Exploring issues of access, participation, equity, effectiveness and sustainability. Journal of Environmental Law, 19(3), 293-321. https://doi.org/10.1093/jel/eqm020

Rayner, S. (2010). How to eat an elephant: A bottom-up approach to climate policy. Climate Policy, 10(2), 615-621. https://doi.org/10.3763/cpol.2010.0138

Ritchie, H., Reay, D. S., \& Higgins, P. (2018). The impact of global dietary guidelines on climate change. Global Environmental Change, 49, 46-55.

Rosenberg, G. N. (2008). The hollow hope: Can courts bring about social change. Chicago, IL: University of Chicago Press.

Roy, S., \& Woerdman, E. (2016). Situating Urgenda v The Netherlands within comparative climate change litigation. Journal of Energy \& Natural Resources Law, 34 (2), 165-189. https://doi.org/10.1080/02646811.2016.1132825

Sands, P. (2016). Climate Change and the rule of law: Adjudicating the future in international law. Journal of Environmental Law, 28(1), 19-35. https:// doi.org/10.1093/jel/eqw005

Schatz, J. (2009). Climate change litigation in Canada and the USA. Review of European Community \& International Environmental Law, 18, 129-138. https:// doi.org/10.1111/j.1467-9388.2009.00635.x

Schiermeier, Q. (2015). Landmark court ruling tells Dutch government to do more on climate change. Nature. Retrieved from https://www.nature.com/news/landmarkcourt-ruling-tells-dutch-government-to-do-more-on-climate-change-1.17841

Setzer, J. (2017). How subnational governments are rescaling environmental governance: The case of the Brazilian state of São Paulo. Journal of Environmental Policy \& Planning, 19(5), 503-519. https://doi.org/10.1080/1523908X.2014.984669

Setzer, J., \& Bangalore, M. (2017). Regulating climate change in the courts. In A. Averchenkova, S. Fankhauser, \& M. Nachmany (Eds.), Trends in climate change legislation (pp. 175-192). London, England: Edward Elgar.

Setzer, J., \& Benjamin, L. (2019). Climate litigation—Regulatory lessons (for the global north) from the global south. Transnational Environmental Law. Manuscript submitted for publication.

Setzer, J., \& Nachmany, M. (2018). National governance: The State's role in steering polycentric action. In A. Jordan, D. Huitema, H. van Asselt, \& J. Forster (Eds.), Governing climate change (pp. 47-62). Cambridge: Cambridge University Press.

Shelton, D. (2003). The environmental jurisprudence of international human rights tribunals. In R. Piolotti \& J. D. Taillant (Eds.), Linking human rights and the environment (pp. 11-18). Tucson, AZ: The University of Arizona Press.

Simma, B. (2012). The international court of justice and scientific expertise. In Proceedings of the ASIL annual meeting (Vol. 106, pp. 230-233). Cambridge: Cambridge University Press. 
Solana, J. (2018). The Power of the Eurosystem to Promote Environmental Protection. University of Oslo Faculty of Law Research Paper No. 2018-23. http: //doi.org/10.2139/ssrn.3241341

Sorenson, Q. M. (2012). Native Village of Kivalina v. ExxonMobil Corp.: The end of climate change tort litigation. Trends, 44(3), 1-6. Retrieved from https:// heinonline.org/HOL/P?h=hein.journals/trends44\&i=85

Spitzer, M., \& Burtscher, B. (2017). Liability for climate change: Cases, challenges and concepts. Journal of European Tort Law, 2017(2), 137-175. https:// doi.org/10.1515/jetl-2017-0009

Starr, D. (2016). The carbon accountant. Science, 353(6302), 858-861. https://doi.org/10.1126/science.353.6302.858

Ugochukwu, B. (2018). Litigating the impacts of climate change: The challenge of legal Polycentricity. Global Journal of Comparative Law, 7, 91-114. https:// doi.org/10.1163/2211906X-00701005

Van Zeben, J. (2015). Establishing a governmental duty of care for climate change mitigation: Will Urgenda turn the tide? Transnational Environmental Law, 4(2), 339-357. https://doi.org/10.1017/S2047102515000199

Vanhala, L. (2013). The comparative politics of courts and climate change. Environmental Politics, 22(3), 447-474. https://doi.org/10.1080/09644016.2013.765686

Vanhala, L. (2016). Legal mobilization under neo-corporatist governance: Environmental NGOs before the Conseil d'Etat in France, 1975-2010. Journal of Law and Courts, 4(1), 103-130. https://doi.org/10.1086/684649

Vanhala, L. (2017). Process tracing in the study of environmental politics. Global Environmental Politics, 17(4), 88-105. https://doi.org/10.1162/GLEP_a_00434

Vanhala, L. (2018). Is legal mobilization for the birds? Legal opportunity structures and environmental nongovernmental organisations in the United Kingdom, France, Finland and Italy. Comparative Political Studies, 51(3), 380-412. https://doi.org/10.1177/0010414017710257

Vanhala, L., \& Hestbaek, C. (2016). Framing climate change loss and damage in UNFCCC negotiations. Global Environmental Politics, 16(4), 111-129. https:// doi.org/10.1162/GLEP_a_00379

Vanhala, L., \& Hilson, C. (2013). Climate change litigation: Symposium introduction. Law \& Policy, 35(3), 141-149. https://doi.org/10.1111/lapo.12007

Vanhala, L., \& Kinghan, J. (2018). Literature review on the use and impact of litigation. The Public Law Project (PLP) Research Paper. Retrieved from https:// publiclawproject.org.uk/wp-content/uploads/2018/04/Literature-Review.pdf

Vollmer, A. R. (2018). Mobilizing human rights to combat climate change through litigation. In Routledge handbook of human rights and climate governance (pp. 359-371). London, England: Routledge.

Watts, K. A., \& Wildermuth, A. J. (2008). Massachusetts v. EPA: Breaking new ground on issues other than global warming. Northwestern University Law Review, 102(1), 1029-1046.

Weaver, R. H., \& Kysar, D. A. (2017). Courting disaster: Climate Change and the adjudication of catastrophe. Notre Dame Law Review, 93(1), 295-356. Retrieved from https://heinonline.org/HOL/P?h=hein.journals/tnd193\&i=305

Wilensky, M. (2015). Climate change in the courts: An assessment of non-U.S. Climate litigation. Duke Environmental Law \& Policy Forum, 26(1), 131-179.

Williams, J. (2012). The impact of climate change on indigenous people-The implications for the cultural, spiritual, economic and legal rights of indigenous people. The International Journal of Human Rights, 16(4), 648-688. https://doi.org/10.1080/13642987.2011.632135

Wuerth, I. (2016, 14 November). International law in the age of trump: A post-human rights agenda. Lawfare blog. Retrieved from https://www.lawfareblog. com/international-law-age-trump-post-human-rights-agenda

Zemans, F. K. (1983). Legal mobilization: The neglected role of the law in the political system. American Political Science Review, 77(3), 690-703. https:// doi.org/10.2307/1957268

How to cite this article: Setzer J, Vanhala LC. Climate change litigation: A review of research on courts and litigants in climate governance. WIREs Clim Change. 2019;e580. https://doi.org/10.1002/wcc.580 